\title{
Metode Job Order Sebagai Strategi Memenangkan Persaingan
}

\author{
Eko Setiobudi \\ Sekolah Tinggi Ilmu Ekonomi Tribuana \\ ekosetiobudi@gmail.com
}

\begin{abstract}
Abstrac
The research was conducted using a case study approach, which is an approach used to investigate and understand an event or problem that has occurred by collecting various kinds of information which is then processed to obtain a solution so that the problems revealed can be resolved, with an emphasis on a certain deeper analysis depth. Specific. The research subjects targeted in this study are; Accounting Section, Production Section, Marketing Section, Finance Section, Project Section and General Section (GA). The objects of this research are (1) the costs used in determining the cost of goods manufactured to be sold by the company, (2) the method of determining the cost of production and the method of determining the selling price of production. As an EMS company, the strategies to win the competition are service quality, capability and price. Pricing strategy is an important part of getting orders or orders from principals. Therefore, the method used is the job order cost method, which is influenced by the number of orders and quality standards. The stages of the pricing strategy include (1) product information, (2) cost variable calculations, (3) HPP determination, (4) price negotiation, (5) MVA creation. And it turns out that in the negotiation process, the agreed price could be below the HPP price or vice versa. Even though it is under HPP, it doesn't necessarily cause a loss, because efficiency can be done during the actual production process during mass production. This efficiency is done by reducing the process or increasing the production output per day. So that a number of orders can be completed in a faster time. Thus, one important aspect in the context of determining the selling price is the company's ability to encourage efficiency and increase its production output capacity.
\end{abstract}

Keywords: Cost Accounting, HPP, Job Order Costing Method

\begin{abstract}
Abstrak
Penelitian dilakukan dengan menggunakan pendekatan studi kasus, yakni pendekatan yang digunakan untuk menyelidiki dan memahami sebuah kejadian atau masalah yang telah terjadi dengan mengumpulkan berbagai macam informasi yang kemudian diolah untuk mendapatkan sebuah solusi agar masalah yang diungkap dapat terselesaikan, dengan menitikberatkan pada kedalaman analisis tertentu yang lebih spesifik. Subyek penelitian yang disasar dalam penelitian ini adalah ; Bagian Akutansi, Bagian Produksi, Bagian Pemasaran, Bagian Keuangan, Bagian Project dan Bagian Umum (GA). Adapun obyek penelitian ini adalah (1) biaya-biaya yang digunakan dalam penentuan harga pokok produksi yang akan dijual oleh perusahaan, (2) metode penentuan harga pokok produksi dan metode penentuan harga jual produksi. Sebagai perusahaan EMS, strategi untuk memenangkan persaingan, yakni kualitas pelayanan, kapabilitas dan harga. Strategi harga menjadi bagian penting untuk mendapatkan order atau pemesanan dari prinsipal. Oleh sebab itu, metode yang dipakai adalah dengan job order cost method yang diantaranya dipengaruhi oleh jumlah pesanan dan standar kualitas. Tahapan strategi harga yang dilakukan antara lain dengan (1) informasi produk, (2) perhitungan variabel biaya, (3) penentuan HPP, (4) negosiasi harga, (5) pembuatan MVA. Dan ternyata dalam proses negosiasi, harga yang disepakti bisa jadi bawah harga HPP atau sebaliknya. Meskipun di bawah HPP, namun tidak serta merta mengalami kerugian, karena dapat dilakukan efisiensi pada saat proses produksi aktual selama mass production. Efisiensi ini dilakukan dengan menguranggi proses ataupun meningkatkan output produksi per harinya. Sehingga sejumlah pemesanan dapat diselesaikan dalam waktu yang lebih cepat. Dengan demikian, salah satu aspek penting dalam konteks menentukan harga jual adalah kepampuan perusahaan untuk mendorong efisiensi dan meningkatkan kapasitas output produksinya.
\end{abstract}

Kata Kunci : Akutansi Biaya, HPP, Job Order Costing Method 


\section{PENDAHULUAN}

Di tengah-tengah dunia yang semakin menglobal tanpa batasan ruang dan waktu, tuntutan bagi Perseroan Terbatas (PT) untuk dapat beradaptasi dengan segala bentuk perubahan zaman menjadi sangat penting, termasuk untuk menjaga daya saing dalam dunia insustri yang sudah sedemikian kompetitif.

Salah satu variabel penting yang akan menentukan kemampuan untuk berkompetisi adalah variabel harga. Harga menjadi salah satu indikator krusial dalam berkompetisi, selain kualitas dan jasa pelayanan lainnya. Namun sampai saat ini, kompetisi harga masih menjadi indikator utama untuk dapat menguasai pangsa pasar dan memenangkan kompetisi. Oleh sebab itu, penentuan harga pokok menjadi bagian penting sekaligus bagian integral untuk dapat menguasai pangsa pasar dan memenangkan kompetisi.

Menurut Mulyadi (2012), penentuan harga pokok produksi adalah cara perhitungan harga pokok suatu barang mulai barang diproduksi sampai barang tersebut selesai dan siap dijual, dimana harga pokok produksi adalah salah satu unsur terpenting dalam penetuan harga

1 Mulyadi, 2001. Akuntansi Manajemen: Konsep, Manfaat dan Rekayasa. Edisi 3 Salemba Empat,Jakarta, hal 23. pokok penjualan ${ }^{1}$. Sementara menurut Supriyono (2000) harga pokok produksi adalah semua elemen biaya baik tetap maupun variabel ${ }^{2}$. Hal yang sama juga disampaikan oleh Bastian dkk (2006) yang mengatakan bahwa penentuan harga pokok adalah bagaimana memperhitungkan biaya pada suatu produk atau pesanan atau jasa yang dapat dilakukan dengan mamasukkan seluruh biaya produksi atau hanya memasukkan biaya variabel saja ${ }^{3}$.

Dengan demikian, apabila penentuan harga pokok produski terlalu tinggi maka harga jualnya akan menjadi tinggi, demikian juga sebaliknya.

Ada berbagai metode dalam penentun harga pokok produksi, seperti metode Full Costing, Activity Base Costing, Variable Costing, serta Job Order Costing. Pemilihan metode tiap-tiap perusahaan memang berbeda-beda sesuai dengan karakteristik bisnis dan industri masing-masing perusahaan. Bagaimanapun perbedaanperbedaan metode tersebut akan mengambarkan perbedaan-perbedaan variabel-variabel biaya dalam melakukan perhitungan dan penentuan harga pokok produksi.

2 Supriyono, 2000. Akuntansi Biaya, Pengumpilan Biaya Dan Penentuan Harga Pokok, Edisi Pertama, BPFE Yogyakarta,hal 288.

3 Bastian, Bustami, Nurlela, 2006, Akuntansi Biaya, Graha Ilmu, Jakarta, hal 40. 
Metode harga pokok pesanan, digunakan oleh perusahaan atau organisasi yang memiliki produk dan jasa yang mudah diidentifikasi menurut unit atau kumpulan individual, dimana masing-masing menerima berbagai masukan bahan baku langsung, tenaga kerja langsung dan overhead pabrik. Metode ini biasanya digunakan oleh perusahaan-perusahaan yang membuat produksinya berdasarkan pesanan, dimana bentuk, kualitas, jumlah unit, sehingga setiap produk memiliki dan karakteristik yang berbeda sesuai keinginan si pemesan ${ }^{4}$. Adapun harga pokok produk perunit setiap perusahaan diperoleh dengan membagi jumlah biaya produksi pesanan tertentu dengan jumlah satuan produk dalam pesanan yang bersangkutan.

Sedangkan metode harga pokok proses adalah suatu metode untuk membebankan biaya ke produk sejenis yang diproduksi secara massal, berkesinambungan lewat serangkaian langkah produksi yang disebut proses $^{5}$. Metode harga pokok proses umumnya dijumpai dalam industri tekstil, kimia, cat, pupuk, perminyakan dan lain sebagainya. Di dalam metode ini, biaya produksi dikumpulkan dalam jangka waktu tertentu untuk setiap pengolahan produk. Harga pokok persatuan produk yang diperoleh dengan membagi jumlah biaya

4 Supriyono, Ibid, hal 36. produk yang telah dikeluarkan selama jangka waktu atau periode tertentu.

Untuk perhitungan jumlah satuan produk yang dihasilkan dalam periode tertentu, maka produk yang masih dalam proses pada akhir periode harus dinyatakan dalam unit yang ekuivalen yaitu berupa satuan produk selesai yang diperkirakan dapat dihasikan dari produk yang masih dalam proses produksi tersebut.Biaya-biaya yang dikeluarkan diikhtisarkan dalam laporan biaya produksi, yang merupakan alat untuk pengumpulan data biaya produksi.

PT. Tridharma Kencana adalah sebuah industri jasa perakitan elektonik atau Electronik Manufacturing Services (EMS) yang beroperasi di Indonesia, dan salama ini menjalankan produksi berdasarkan pada pesanan atau order yang diterima dari konsumen. Dengan demikian, penentuan harga pokok dilakukan berdasarkan pada pesanan, yang antara lain juga dipengaruhi oleh dengan jumlah pesanan, spesifikasi, model, tipe dan lain sebagainya.

Dengan demikian, dalam penelitian ini akan mengunakan metode Job Order Costing Method sesuai dengan karakter bisnis yang ada di PT. Tridharma Kencana. Adapun menurut Supriyono (2000) metode Job Order Costing adalah metode pengumpulan harga pokok dimana biaya dikumpulkan untuk setiap pesanan atau 
kontrak atau jasa secara terpisah dan setiap pesanan atau kontrak dapat dipisahkan identitasnya. Metode pesanan biasanya digunakan oleh perusahaan-perusahaan yang membuat produksinya berdasarkan pesanan, bentuk dan kualitas produk dibuat sesuai keinginan pemesan sehingga setiap produk memiliki sifat yang berbeda. Produk dibuat berdasarkan pesanan dan bukan untuk memenuhi stok gudang ${ }^{6}$.

Berdasarkan pada uraian tersebut di atas, maka rumusan masalah yang diajukan dalam penelitian ini adalah bagaimanakah strategi harga yang dilakukan oleh perusahaan untuk menentukan harga pokok produksi dengan mengunakan Job Order Method dan bagaimanakah cara penentuan harga pokok produksinya?

\section{METODOLOGI PENELITIAN}

Penelitian dilakukan dengan menggunakan pendekatan kualitatif deskriptif. Penelitian deskriptif adalah suatu bentuk penelitian yang ditujukan untuk mendeskripsikan fenomena- fenomena yang ada, baik fenomena alamiah maupun fenomena buatan manusia.

6 Supriyanto, Ibid, hal 36.

7 J. Amos Hatch, 2002. Doing Qualitative Research In Education Setting, State University Of New York Press, New York, hal 6-11.

${ }^{8}$ Norman K. Denzin \& Yvonna S. Lincoln,2009, Handbook of Qualitative Research (terjemahan), Pustaka Pelajar, Yogyakarta, hal 6.
J.Amos Hatch menyebutkan bahwa beberapa karakteristik dari penelitian kualitatif, diantaranya adalah :

Pengaturan alami, (2) Perspektif peserta, (3)

Peneliti sebagai pengumpulan data instrumen, (4) Diperpanjang tangan pertama engagement, (5) Sentralitas arti, (6) Keutuhan dan kompleksitas,

Subyektivitas, (8) Munculnya desain, (9) Analisis data induktif, (10) Refleksivitas ${ }^{7}$. Norman K. Denzin \& Yvonna S. Lincoln, bahwa penelitian kualitatif menekankan sifat realitas yang terbangun secara sosial, hubungan erat antara peneliti dengan subyek yang diteliti, dan tekanan situasi yang membentuk penyelidikan ${ }^{8}$. Para peneliti semacam ini mementingkan sifat penyelidikan yang sarat nilai. Pendapat tersebut tidaklah berlebihan karena, menurut Rossi dan Freeman, dalam penelitian kualitatif instrumen pokoknya adalah peneliti, sehingga tidak mustahil akan dapat mengungkap latar-latar perilaku dan pengalaman manusiawi dari kerangka acuan subjek penelitian (aktor) itu sendiri ${ }^{9}$.

Berdasarkan pada rumusan masalah dan uraian tersebut diatas, maka penelitian ini mengunakan jenis pendekatan studi

\footnotetext{
${ }^{9}$ Peter H. Rossi, Howard E. Freeman \& Mark W. Lipsey, 1998. Evaluation, A Systematic Approach Sixth Edition, SAGE Publications.lnc, California hal 269-271
} 
kasus. Penelitian studi kasus menurus Creswell merupakan jenis pendekatan yang digunakan untuk menyelidiki dan memahami sebuah kejadian atau masalah yang telah terjadi dengan mengumpulkan berbagai macam informasi yang kemudian diolah untuk mendapatkan sebuah solusi agar masalah yang diungkap dapat terselesaikan ${ }^{10}$.

Dengan demikian, penelitian studi kasus merupakan suatu metode untuk memahami individu yang dilakukan secara integrative dan komprehensif agar diperoleh pemahaman yang mendalam tentang individu tersebut beserta masalah yang dihadapinya dengan tujuan masalahnya dapat terselesaikan dan memperoleh perkembangan diri yang baik. Adapun yang membedakan penelitian dengan pendekatan studi kasus dengan jenis pendekatan penelitian kualitatif yang lain terdapat pada kedalaman analisisnya pada sebuah kasus tertentu yang lebih spesifik. Analisis dan triangulasi data juga digunakan untuk menguji keabsahan data dan menemukan kebenaran objektif sesungguhnya. Metode ini sangat tepat untuk menganalisis kejadian tertentu di suatu tempat tertentu dan waktu yang tertentu pula.

Pengambilan sampel penelitian dalam penelitian studi kasus dilakukan secara

10 Creswell, 2014. Research Design, Pendekatan Kualitatif, Kuantitatif dan Mixed (Terjemahan purposif karena dalam penelitian kualitatif apa yang akan dicari adalah masalah yang alami sehingga tidak semua orang dapat dijadikan sampel. Penelitian kualitatif juga tidak terlalu dibutuhkan random sampling atau pemilihan secara acak terhadap para partisipan atau informan dan lokasi penelitian. Karenannya pembahasan mengenai informan atau partisipan dan lokasi penelitian dapat mencakup empat aspek: (1) lokasi penelitian, (2) aktor, (3) peristiwa dan, (4) proses. Jika dikaji dari perspektif ini, sample penelitian yang dijadikan sebagai informan dalam penelitian ini terdiri dari beberapa kelompok, yakni: (1) Kepala Departemen; (2) Kepala Divisi; (3) Manager dan Asisten Manager.

Subyek penelitian yang disasar dalam penelitian ini adalah ; Bagian Akutansi, Bagian Produksi, Bagian Pemasaran, Bagian Keuangan, Bagian Project dan Bagian Umum (GA). Adapun obyek penelitian ini adalah (1) biaya-biaya yang digunakan dalam penentuan harga pokok produksi yang akan dijual oleh perusahaan, (2) metode penentuan harga pokok produksi dan metode penentuan harga jual produksi.

Adapun pembatasan jumlah sample sebanyak 20 orang. Jumlah ini dianggap

Edisi Ketiga), Pustaka Pelajar, Yogyakarta, hal 260. 
cukup dan sejalan dengan pendapat Emzir ${ }^{11}$, yang peneliti biasanya melakukan 20-30 wawancara berdasarkan beberapa pertemuan dilapangan untuk mengumpulkan data.

Proses pengambilan data primer yang digunakan oleh peneliti adalah hasil dari wawancara dengan informan serta observasi lapangan. Data sekunder adalah datadata perusahan yang diberikan kepada peneliti, maupun buku, dan jurnal serta koran. Dalam melakukan penelitian ini, peneliti menggunakan beberapa cara dalam pengumpulan data, yaitu:

1. Wawancara

Teknik wawancara adalah teknik mengumpulkan data atau informasi dengan cara bertatap muka langsung dengan informan agar mendapatkan data lengkap dan mendalam. Wawancara ini dilakukan dengan frekuensi tinggi (berulang-ulang) secara intensif. Peneliti akan melakukan wawancara semi terstruktur, guna untuk mendapatkan ide-ide yang lebih terbuka dan mendalam. Oleh karena itu peneliti menyiapkan pedoman wawancara.

2. Observasi

Definisi Observasi lapangan atau pengamatan lapangan (field

11 Emzir, 2012 Metodologi Penelitian Pendidikan Kuantitatif \& Kualitatif, Edisi Revisi, Jakarta; PT RajaGrafindo Persada, hal 209. observation) adalah kegiatan yang setiap saat dilakukan, dengan kelengkapan pancaindra yang dimiliki. Selain dengan membaca Koran, mendengarkan radio, menonton televisi atau berbicara dengan orang lain, kegiatan obsevasi merupakan salah satu kegiatan untuk memahami lingkungan. Peneliti akan melakukan observasi langsung di lapangan tempat lokasi penelitian. Guna dari melakukan observasi ini adalah agar peneliti dapat melihat langsung keadaan yang terjadi dalam internal dan eksternal perusahaan.

Tekhnik analisa data dalam penelitian kualitatif menurut Creswell (2003) dilakukan melalui langkah-langkah : Langkah (1) mengolah dan mempersiapkan data untuk dianalisis. Langkah (2) Membaca keseluruhan data. Langkah (3) menganalisis lebih detail dengan meng-coding data. Langkah (4) terapkan proses coding untuk mendeskripsikan setting, orang-orang kategori-kategori dan tema-tema yang akan dianalisis. Langkah (5) tunjukkan bagaimana deskripsi dan tema-tema ini akan disajikan kembali dalam narasi/laporan kualitatif $^{12}$. Sementara Miles dan Huberman

\footnotetext{
${ }^{12}$ Creswell, Ibid, hal 276-284
} 
menegaskan bahwa ada tiga tahapan dalam analisis data, yaitu ${ }^{13}$ :

1. Reduksi data (Data Reduction). Setelah data dikumpulkan, peneliti melakukan seleksi data sesuai dengan fokus penelitian. Data yang kurang relevan atau kurang berhubungan dengan fokus penelitian direduksi agar lebih mudah dalam meringkas dan membuat abstraksi terhadap data mentah, sehingga menjadi jelas. Reduksi data ini merupakan proses pemilihan, memfokuskan pada penyederhanaan, pengabstraksian dan transformasi data mentah yang muncul dari data catatan-catatan tertulis dilapangan. Reduksi data merupakan bentuk analisis yang menajamkan hal-hal yang penting, membuang hal-hal yang tidak relevan dengan fokus penelitian agar sistematis dan bermakna.

2. Menyajikan data (Display Data). Penyajian data merupakan proses penyampaian sejumlah informasi yang sudah disusun, yang memungkinkan untuk menarik kesimpulan dan pengambilan tindakan. Penyajian data merupakan gambaran secara keseluruhan dari sekelompok data yang diperoleh agar mudah dibaca secara menyeluruh. Pada tahap ini data dapat disajikan dalam bentuk narasi, matriks, grafik dan didiskusikan dengan berbagai pihak dan sumber. Dengan menyajikan data, peneliti dapat memahami apa yang terjadi dalam penelitian baik menyangkut validitas data maupun hal-hal yang kurang dalam penelitian.

3. Membuat kesimpulan (Conclusion drawing/Verification). Pada tahap ini peneliti membuat kesimpulan dan memverifikasi serta mencocokkan kembali pada data atau hasil lapangan atau menelaah dengan sejawat. Kemudian diproses agar menjadi data yang siap disajikan untuk selanjutnya dibuat kesimpulan hasil penelitian. Kesimpulan merupakan suatu konfigurasi yang utuh. Selanjutnya dijelaskan bahwa analisis data ini dilakukan semenjak pengurnpulan data, artinya tidak harus menunggu data itu terkumpul semua tetapi dalam waktu proses pengurnpulan data pun dapat dilakukan analisis data.

\section{HASIL DAN PEMBAHASAN}

Di PT. Tridharma Kencana istilah Harga Pokok Produksi (HPP) dikenal dengan istilah Manufacture Value Added (MVA). Karena banyaknya produk dan tipe, menyebabkan harga juga berbeda-beda. Oleh sebab itu, dalam penelitian ini, penulis akan mengunakan sample data perhitungan Harga

\footnotetext{
${ }^{13}$ Matthew B. Miles dan A. Michael Huberman, 1992, Analisis Data Kualitatif (Terjemahan), Penerbit UI Press , Jakarta, hal 16-20.
} 
Pokok Produksi (HPP) untuk LED TV Merk

Haier dengan ukuran 19 sampai 24 Inci. Adapun strategi harga dilakukan dengan :

\section{Informasi Produk}

Strategi harga dilakukan dengan mengunakan penentuan biaya dalam rangka melakukan perhitungan HPP dari semua order yang dipesan oleh prinsipal, maka perusahaan harus mendapatkan informasi awal dari prinsipal. Informasi awal tersebut terdiri ;

a. Build Of Material list (BOM), yakni jenis-jenis material atau part yang dibutuhkan untuk membuat sebuah produk.

b. Standar Operasional Prosedure (SOP). Informasi ini dibutuhkan dengan tujuan untuk melakukan perhitungan jumlah tenaga kerja yang dibutuhkan untuk melakukan proses perakitan atau produksi produk tersebut.

c. Spesifikasi produk, dimana informasi ini dibutuhkan untuk memastikan bahwa standar kualitas yang dirpoduksi oleh perusahaan adalah sama persis atau identik dengan produk yang dibuat di negara asalnya.

d. Jumlah produk yang dipesan (quantity), hal ini untuk menentukan besaran biaya yang dikeluarkan khususnya untuk membagi biaya- biaya tetap, sehingga biaya per unitnya menjadi lebih kecil.

\section{Variabel Biaya}

Setelah mendapatkan informasiinformasi tersebut di atas, perusahaan akan melakukan perhitungan HPP atau MVA yang kemudian akan disampaikan kepada pihak prinsipal. Untuk lebih detail mengenai proses penentuan dan perhitungan HPP yang ada di PT. Tridharma Kencana maka dilakukan prosesnya sebagai berikut :

a. Biaya tenaga kerja baik itu tenaga kerja langsung maupun tenaga kerja tidak langsung. Perhitungan biaya tenaga kerja, terdiri dari tenaga kerja langsung dan tenaga kerja tidak langsung. Tenaga kerja langsung atau direct labour adalah operator atau tenaga kerja yang bersentuhan secara langsung dalam proses produksi perakitan. Dengan demikian, bobot biayanya adalah $100 \%$. Sementara tenaga kerja tidak langsung atau indirect labour adalah tenaga kerja yang tidak bersentuhan secara langsung dengan proses produksi perakitan., dengan bobot biaya bervariasi mulai dari $100 \%$ untuk level leader sampai dengan supervisor dan bonot $8,3 \%$ untuk level lainnya seperti security dan manager. Adapun rincian biaya-biaya tenaga kerja terdiri dari ; gaji (yakni Upah Minimum Kabupaten/Kota Sektoral/UMKS), BPJS Ketenagakerjaan, BPJS Kesehatan, BPJS 
Pensiun, Medical, THR dan meal/transportasi.

\section{b. Biaya material pendukung/pembantu} atau dikenal dengan consumable cost.

Biaya material pendukung adalah bagian dari komponen perhitungan Tingkat Kadungan Dalam Negeri (TKDN). Oleh sebab itu, komponen material pendukung atau disebut dengan istilah consumable dilakukan pembelian di dalam negeri, bukan di import. Beberapa komponen material pendukung untuk produk LED TV sebagaimana data MVA, adalah SN Lable, Inner Box Seal Label, Ribbon wax, Type Lable, Nameplate label, Quick Start Guide, Outer box label, Certificate in English and Chinese (incl. 1year warranty), Seal Sticker, Inner box, Plastic-film bag, Outer box, Packing Tape, Striping band, Paper Edge, Carton Layer, Strecth Film dan Screw. Dengan total biaya pembelian untuk setiap unit material pendukung tersebut adalah sebesar Rp 1.521,2.

\section{c. Biaya fasilitas dan infrastruktur. Biaya} fasilitas dan infrastruktur terdiri dari tiga kompoonen biaya, yakni biaya gedung, listrik dan telekomunikasi atau telpon. Biaya ini dibebankan kepada konsumen sesuai dengan bobot nya. Untuk gedung alokasi bobotnya adalah 30\%, untuk listrik alokasi bobotnya adalah 30\% dan untuk telepon alokasi bobotnya adalah

$12 \%$. Dari total biaya sewa dan bobot ini kemudian dibagi dengan jumlah quantity yang diproduksi. Dimana setiap 1 unit IPTV, dibebankan biaya sejumlah Rp $1.568,37$.

\section{d. Biaya mesin dan alat termasuk} depresiasi. Biaya mesin artinya adalah biaya penggunaan mesin untuk memproduksi 1 unit LED TV. Dimana besaran biaya penggunaan mesin ini terdiri dari 2 (dua) variabel, yakni depresiasi dan alokasi bobot dari mesinmesin tersebut. Mesin-mesin tersebut diantaranya adalah Belt Conveyor, Generator Set, Compressor, Copper foil, Zebra printer 105, Tooling\&Karet RRU dan lain-lain. Dimana untuk membuat LED TV dibutuhkan 12 mesin produksi, dengan pembobotan pada biaya yang berbeda-beda. Ada yang 100\%, 30\% dan $8,3 \%$. Besarnya pembobotan ini tergantung dari utilitation mesin terpakai untuk membuat sebuah produk.

e. Biaya motor vihicle. Biaya motor vihicle adalah alokasi pengunaan dua jenis alat pengangut yang digunakan sebagai jasa pendukung produksi. Dalam hal ini pengunaan motor vihicle, terdiri dari truk untuk pengiriman barang jadi kepada prinsipal serta serta pengunaan forklip untuk pengangkutan barang jadi kedalam truk. Alokasi pengunaan forklip adalah sebesar $8,3 \%$ dan truk adalah 
sebesar 8,3\%. Dan jika ditotal maka alokasi biaya yang digunakan untuk setiap unit LED TV adalah sebesar Rp 1.161,95.

\section{f. Biaya lain-lain yang meliputi} maintenance, calibrasi, sertifikasi dan lain sebagainya. Selain biaya-biaya tesebut di atas, masih terdapat beberapa biaya lain-lain, yang diantaranya adalah biaya mantenance, calibras, sertifikasi, asuransi, training dan lain sebagainya. Pembobotan atau alokasi pengunaanya juga berbeda-beda, ada yang $100 \%$ seperti pengunaan internet, ada yang $10 \%$ seperti pengunaan jasa sertifikasi ISO 9001 dan pajak air tanah, serta ada yang $2 \%$ seperti pengunaan BBM yang dalam hal ini adalah solar. Dari semua alokasi biaya maintenance dan lain-lain seperti tersebut di atas total biaya untuk membuat 1 (satu) unit LED TV adalah sebesar Rp 1.449,62.

\section{Penentuan HPP}

Berdasarkan pada data-data tersebut di atas, diketahui bahwa PT. Tridharma Kencana sebagai perusahaan jasa perakitan perangkat elektronik dan telekomunikasi, yang dalam proses produksinya hanya melakukan jasa perakitan. Sehingga perusahaan tidak mengeluarkan biaya pembelian bahan baku, karena bahan baku sudah disiapkan oleh prinsipal selaku pihak pemesan. Yang disiapkan oleh perusahaan hanyalah bahan baku material pendukung.
Dan setelah semua variabel biaya diketahui, sebagaimana yang sudah disebutkan di atas, maka strategi berikutnya adalah pembuatan Kartu HPP pada jasa perakitan perangkat elektronik dan telekomunikasi yang dalam hal ini adalah LED TV. Dimana istilah ini di PT. Tridharma Kencana disebut dengan istilah MVA, yang terdiri dari :

a. Material pendukung. Biaya material pendukung adalah biaya material yang digunakan untuk memenuhi persyaratan komponen Tingkat Kandungan Dalam Negeri (TKDN).

b. Biaya tenaga kerja, yakni tenaga kerja langsung dan tenaga kerja tidak langsung. Biaya tenaga kerja terdiri dari dua komponen biaya, yakni tenaga kerja langsung yakni tenaga kerja yang bersentuhan langung dengan proses produksi seperti operator produksi, operator QC, operator gudang dan lain sebagainya. Sedangkan biaya tenaga kerja tidak langsung adalah tenaga kerja yang tidak bersentuhan secara langsung dengan proses produksi, diantaranya adalah leader, supervisor, dan manager. Bagi tenaga kerja yang bersentuhan secara langsung maka bobot atau beban alokasi biayanya adalah 100\% dan bagi tenaga kerja tidak langsung 
beban atau bobot biayanya bervariasi, mulai dari $8,3 \%$ sampai dengan $100 \%$.

\section{c. Biaya manufactur expenditure} (manex). Biaya manufaktur expenditure atau belanja manufaktur terdiri dari berbagai manex. (1) Manex 1 adalah jenis biaya yang terdiri dari variabel biaya lisensi dan asuransi. Lisensi dalam hal ini adalah sertifikasi ISO 9001 tentang Manajemen Mutu, dan biaya asuransi yang dalam hal ini adalah biaya asuransi pabrik, (2) Manex 2 adalah biaya sewa gedung yang juga dialokasikan pada beban biaya jasa produksi perakitan IPTV. Adapun beban atau bobot biaya sewa gedung yang dialokasikan adalah sebesar 30\%. (3) Manex 3 adalah alokasi biaya untuk pengunaan elektricity yang dalam hal ini adalah biaya listrik dan telepon. Adapun beban atau pembobotan biaya listrik adalah sebesar $30 \%$ dan telepon adalah sebesar 12\%. (4) Manex 4 adalah alokasi biaya yang digunakan untuk pengunaan mesin-mesin produksi. Dalam hal produksi IPTV mesinmesin yang digunakan adalah sebanyak 12 mesin, dengan alokasi beban atau pembobotan yang berbeda-beda, mulai dari $8,3 \%$ seperti mesin generator set, $30 \%$ seperti UPS APC, serta 100\% seperti belt conveyor. (5) Manex 5 adalah alokasi biaya yang dibebankan untuk pengunaan jasa angkutan, yakni truk yang digunakan untuk mengirimkan barang jadi ke prinsipal serta forklip yang digunakan untuk menaikkan brang jadi kedalam truk. Alokasi beban atau bobot pengunaan forklip dan truk untuk produksi LED TV adalah sebesar $8,3 \%$.

d. Biaya consumable. Biaya consumable adalah alokasi biaya yang digunakan untuk melakukan pembelian produk yang habis pakai dan digunakan sebagai proses pendukung produksi. Diantaranya adalah pembelian alkohol, wraping, seal atau lakban, lem dan lain sebagainya. Dalam proses perakitan atau produksi LED TV dibutuhkan sebanyak 10 jenis barang consumable degan rata-rata pembobotannya adalah sebesar $100 \%$ kecuali untuk clean room weeper yang dialokasikan bobotnya sebesar $30 \%$.

\section{e. Biaya tidak langsung pabrik (untuk} jasa-jasa terkait). Biaya tidak langsung pabrik adalah biaya-biaya maintenance, sertifikasi, calibrasi dan lain sebagainya. Total variabel 
biaya tidak langsung untuk memproduksi LED TV terdiri dari 11 jenis biaya dengan bobot alokasi pembebanan biaya yang berbedabeda, mulai dari $2 \%$ seperti $\mathrm{BBM}$ (solar), 10\% seperti PBB, dan 100\% seperti calibrasi.

Semua biaya-biaya tersebut, khususnya dalam pembuatan LED TV kemudian direkapitulasi dalam kartu harga pokok sebagaimana yang bisa dilihat alam tabel berikut :

Tabel 1 : Rekapitulasi Biaya LED TV (19-24 Inc)

\begin{tabular}{|l|l|}
\hline Item (BOM Cost) & $\begin{array}{l}\text { Harga/Unit } \\
(\mathrm{Rp})\end{array}$ \\
\hline Direct labour & $14.054,74$ \\
\hline Indirect Labour & $24.205,48$ \\
\hline Consumable & $1.521,20$ \\
\hline Facilities \& Infrastructure & $1.568,37$ \\
\hline $\begin{array}{l}\text { Equipment \&ools } \\
\text { Depreciation }\end{array}$ & $2.066,78$ \\
\hline $\begin{array}{l}\text { Other ISO } \\
\text { calibration cost, } \\
\text { certification fee,insurance) }\end{array}$ & $1.449,72$ \\
\hline Motor vihicle & $1.161,95$ \\
\hline Fee & 7.500 \\
\hline Total MVA 53.528,13 \\
\hline Sumber, MVA TDK, 2018
\end{tabular}

Sumber, MVA TDK, 2018

Dengan demikian, jelas bahwa dalam metode perhitungan Harga Pokok Produksi (HPP) yang digunakan di PT. Tridharma Kencana adalah dengan mengunakan metode harga pokok pesanan atau job order method. Hal ini sangat wajar karena sebagaimana yang sudah dikemukakan sebelumnya bahwa PT Tridharma Kencana adalah perusahaan EMS atau perusahaan jasa perakitan perangkat elektronik dan telekomunikasi.

Metode perhitungan HPP oleh PT. Tridharma Kencana dilakukan dengan tahap awal mengidentifikasi jenis dan spesifikasi produk, baik dari sisi SOP yang digunakan, spesifikasi produk, serta jumlah unit yang dipesan. Semua informasi tersebut dibutuhkan sebagai tahap awal untuk megidentifikasi jenis-jenis biaya yang akan digunakan untuk memproduksi sebuah produk. Kemudian dikelompokkan dalam biaya-biaya atau sheet biaya untuk memudahkan pencatatan dan perhitungan harga pokok produksi ke dalam kartu harga pokok produksi (HPP). Adapun harga pokok produk perunit diperoleh dengan membagi jumlah biaya produksi pesanan tertentu dengan jumlah satuan produk dalam pesanan yang bersangkutan. Dan dari tabel tersebut di atas, diketahui bahwa HPP untuk setiap unit LED TV ukuran 19 sampai 24 Inci adalah sebesar RP 53.528,13.

\section{Negosiasi Harga}

Setelah mendapatkan perhitungan HPP dalam kartu HPP, maka pihak marketing akan melakukan penawaran atau bidding kepada prinsipal selaku pemilik brand. Dalam proses inilah, negosiasi harga akan bahas dan didiskusikan antara pihak 
marketing PT. Tridharma Kencana dengan pihak Procurment prinsipal.

Dalam proses negosiasi dipastikan ada proses tawar menawar harga, seringkali harga dalam Kartu HPP bisa ditawar lebih rendah. Hal ini wajar, sebagaimana lazimnya sebuah proses jual beli atau perdagangan. Dan setelah disepakati harganya per unit, maka akan dituangkan dalam sebuah quotation yang disebut dengan Manufactur Value Added (MVA).

\section{Pembuatan MVA}

Manufactur Value Added (MVA) adalah quotation harga per unit untuk jasa perakitan sebuah produk, dimana harganya sudah disepakati antara kedua belah pihak dengan mengacu pada kartu HPP. Untuk selanjutnya ditambahkan dengan biaya jasa atau fee yang notabene adalah margin bagi perusahaan.

Sehingga setelah diketahui Harga Pokok Produksinya (HPP) keuntungan atau margin yang diperoleh PT. Tridharma Kencana adalah biaya jasa atau yang disebut dengan istilah TDK Fee yang dihitung fee dari produksi LED TV per unit. Dari kartu HPP atau rekapitulasi biaya ditambah dengan fee atau biaya jasa perakitan, kemudian dituangkan dalam MVA. Dengan demikian, bisa jadi harga dalam MVA lebih kecil dibandingkan dengan HPP per unitnya ataupun sebaliknya, tergantung dari proses negosiasi antara kedua belah pihak.
Untuk contoh kasus LED TV tersebut diketahui bahwa harga dalam kartu HPP adalah sebesar Rp 46.028,13 per unit dan di tambah dengan TDK fee sebesar Rp 7.500 per unit, sehingga total MVA untuk LED TV ukuran 19 sampai 24 Inci adalah sebesar RP $53.528,13$.

Dan setelah negosiasi dengan prinsipal atau pemesan disepakati bahwa MVA yang terdiri dari HPP ditambah fee adalah sebesar RP 5.000 per unit. Artinya ada selisih sebesar Rp 2.500 per unit, dengan MVA sebesar Rp 51.028,13 Hal ini bisa dilihat dari tabel berikut.

Tabel 2 : MVA LED TV (19-24 Inc)

\begin{tabular}{|l|l|}
\hline Item (BOM Cost) & $\begin{array}{l}\text { Harga/Unit } \\
(\mathrm{Rp})\end{array}$ \\
\hline Direct labour & $14.054,74$ \\
\hline Indirect Labour & $24.205,48$ \\
\hline Consumable & $1.521,20$ \\
\hline Facilities \& Infrastructure & $1.568,37$ \\
\hline $\begin{array}{l}\text { Equipment \& Tools } \\
\text { Depreciation }\end{array}$ & $2.066,78$ \\
\hline $\begin{array}{l}\text { Other ISO } \\
\text { calibration cost, } \\
\text { certification fee,insurance) }\end{array}$ & $1.449,72$ \\
\hline Motor vihicle & $1.161,95$ \\
\hline Fee & 5.000 \\
\hline Total MVA 51.028,13 \\
\hline
\end{tabular}

Sumber : MVA TDK, 2018

Dengan penurunan harga ini tidak serta merta PT. Tridharma Kencana mengalami kerugian. Tetapi strategi yang dilakukan adalah dengan menaikkan hasil produksi atau output per hari. Dalam perhitungan dalam kartu HPP IPTV B860H, dasar 
perhitungan hasil produksi per hari adalah sebesar 350 unit. Tetapi dalam proses produksi aktual selama mass production LED TV ukuran 19 sampai 24 inci dengan jumlah tenaga kerja baik tenaga kerja langsung maupun tenaga kerja tidak langsung serta pengunaan mesin dan fasilitas produksi yang ada akan terjadi yang disebut learning curve atau hasil produksi yang akan terus meningkat seiring dengan peningkata keahlian tenaga kerja langsung (skill). Dimana untuk aktual hasil produksi dilapangan bisa meningkat diangka 550 sampai 600 unit per hari dengan learning curve selama 3 hari. Artinya hasil produksi atau output produksi LED TV ukuran 19 sampai 24 inci mengalami kenaikan rata-rata sebesar 57 sampai 60 persen.

Artinya, untuk pemesaann sebesar 10.000 unit dimana dalam MVA seharusnya diselesaikan dalam waktu 28 hari, aktualnya bisa diselesaikan dalam waktu 18 hari.

Efisiensi inilah yang menjadi alasan, meskipun harga MVA nya lebih rendah dari HPP, namun PT. Tridharma Kencana tetap tidak mengalami kerugian, karena adanya efisiensi waktu (hari) produksi. Sehingga pengunaan biaya-biaya yang lain bisa dikuranggi secara signifikan, khususnya variabel cost seperti gaji tenaga kerja.

\section{KESIMPULAN}

PT. Tridharma Kencana sebagai perusahaan jasa perakitan (EMS) memang tidak melakukan penjualan hasil produksinya secara langsung kepada konsumen. Namun membuat produk berdasarkan pada pesanan prinsiplal selaku pemilik brand. Dalam konteks ini, maka strategi untuk memenangkan persaingan dengan perusahaan yang lain secara prinsip meliputi beberapa hal, yakni kualitas pelayanan, kapabilitas dan harga.

Strategi harga sebagai salah satu strategi dakam berkompetisi menjadi bagian penting untuk mendapatkan order atau pemesanan dari prinsipal. Oleh sebab itu, metode yang dipakai adalah dengan job order cost method yang diantaranya dipengaruhi oleh jumlah pesanan serta standar kualitas dari produk itu sendiri. Dimana tahapan-tahapan strategi harga yang dilakukan antara lain dengan (1) informasi produk, (2) perhitungan variabel biaya, (3) penentuan HPP, (4) negosiasi harga, (5) pembuatan MVA.

Dan ternyata dalam proses negosiasi, harga yang disepakti bisa jadi bawah harga HPP atau sebaliknya. Meskipun di bawah HPP, namun tidak serta merta mengalami kerugian, karena dapat dilakukan efisiensi pada saat proses produksi aktual selama mass production. Efisiensi ini dilakukan dengan menguranggi proses ataupun 
meningkatkan output produksi per harinya. Sehingga sejumlah pemesanan dapat diselesaikan dalam waktu yang lebih cepat.

\section{REFERENCES}

Amos Hatch J, 2002. Doing Qualitative Research In Education Setting, State University Of New York Press, New York

Anselm Straus, dan Juliet Corbin, 2003. Dasar-dasar Penelitian Kualitatif: Tatalangkah dan Teknik-teknik Teoretisasi Data, Penerjemah,

Muhammad Shodiq dan Imam Mutaqien, Pustaka Pelajar, Yogyakarta

Bastian, Bustami, Nurlela, 2006, Akuntansi Biaya, Graha Ilmu, Jakarta

Emzir, 2012 Metodologi Penelitian Pendidikan Kuantitatif \& Kualitatif, Edisi Revisi, Jakarta; PT RajaGrafindo Persada

John W Creswell, 2014. Research Design, Pendekatan Kualitatif, Kuantitatif dan Mixed (Terjemahan Edisi Ketiga), Pustaka Pelajar, Yogyakarta

\section{Matthew B. Miles dan A. Michael}

Huberman, 1992, Analisis Data Kualitatif (Terjemahan), Penerbit UI Press , Jakarta

Mulyadi, 2001. Akuntansi Manajemen: Konsep, Manfaat dan Rekayasa. Edisi 3 Salemba Empat, Jakarta
Peter H. Rossi, Howard E. Freeman \& Mark W. Lipsey, 1998. Evaluation, A Systematic Approach Sixth Edition, SAGE Publications.lnc, California

Supriyono, 2000. Akuntansi Biaya, Pengumpilan Biaya Dan Penentuan Harga Pokok, Edisi Pertama, BPFE Yogyakarta 